\title{
Resistivity profiles of Perth soil in Australia in leak-detection test
}

Lopa Mudra S. Pandey MScEng

$\mathrm{PhD}$ candidate, School of Engineering, Edith Cowan University, Perth, Australia (corresponding author: Impandey@our.ecu.edu.au; mail.lopa@gmail.com) (Orcid:0000-0001-5393-9124)
Sanjay Kumar Shukla PhD

Associate Professor and Program Leader, School of Engineering,

Edith Cowan University, Perth, Australia (Orcid:0000-0002-4685-5560)

Daryoush Habibi PhD

Professor, School of Engineering, Edith Cowan University, Perth, Australia

The use of a suitable leak-detection system for the prevention and mitigation of pollution due to lining system failures is integral to the proper management of landfill facilities. This paper briefly summarises various methods of leak detection that are currently being practised. The details of a newly developed leak-detection technique are also presented. The tests were conducted to evaluate the performance of the new technique by use of controlled leakage. The resulting resistivity profiles for Perth soil in Australia were obtained at 10 min. This method is found to be effective in detecting and locating liner leakage issues within $\mathbf{3 0 ~} \mathrm{min}$ from the instant when the defect develops. The electrical resistivity decreases with an increase in the leakage duration. The resistivity was found to increase with an increase in the distance/depth from the leak point. Installation of this innovative detection system below liners can enable the various waste containment facilities, such as landfills and leachate ponds, to monitor the lining systems and in case of failures, to take timely action for hazard mitigation. Results presented in this study can be useful for further development of sensors for leakage detection in lining systems.

\section{Notation}

A cross-sectional area of the specimen: $\mathrm{m}^{2}$

$C_{\mathrm{C}} \quad$ coefficient of curvature (dimensionless)

$C_{\mathrm{u}} \quad$ coefficient of uniformity (dimensionless)

$D_{10} \quad$ effective size of the soil particles: $\mathrm{mm}$

$D_{\mathrm{r}} \quad$ relative density (dimensionless)

$G_{\mathrm{s}} \quad$ specific gravity of soil solids (dimensionless)

$i \quad$ input current: A

$k \quad$ hydraulic conductivity: $\mathrm{m} / \mathrm{s}$

$L \quad$ length of the specimen: $m$

$R \quad$ electrical resistance: $\Omega$

$t \quad$ duration for which leakage through the liner was allowed/leakage duration: min

$V$ potential difference across the outer conductors/input voltage: $\mathrm{V}$

Z

$\gamma_{\mathrm{d} \max }$ maximum dry unit weight of soil: $\mathrm{kN} / \mathrm{m}^{3}$

$\gamma_{\mathrm{d} \text { min }}$ minimum dry unit weight of soil: $\mathrm{kN} / \mathrm{m}^{3}$

$\rho \quad$ electrical resistivity of the soil: $\Omega \mathrm{m}$

\section{Introduction}

The global population generates a huge amount of waste every year. The World Bank has estimated that the amount of municipal solid waste (MSW) generated worldwide will be doubled in the period 2012-2025 (Hoornweg and Bhada-Tata, 2012). In Australia alone, waste generation increased by $170 \%$ in the period 1996-2015 at a compound growth rate of $7 \cdot 8 \%$ per annum (Dewha, 2010). About $42 \%$ of this waste went to landfills, while the rest was diverted to resource recovery centres. Specifically, in Western Australia (WA), landfilling is the usual method of waste disposal (Schollum, 2010). In 2014-2015, 58\% of the total waste generated in WA was sent to landfills (Waste Authority, 2016). These solid wastes consisted of commercial and industrial wastes, construction and demolition wastes and MSWs (Goldsworthy, 2010; Perryman and Green, 2017). The leachates produced by these wastes contain multiple pollutants (O'Kelly, 2016), which can prove to be potentially harmful to the environment (Bouazza and Van Impe, 1998; Daniel, 1993). Therefore, the problems of safe handling, storage and disposal of wastes become very daunting challenges faced by landfills (Hoyos et al., 2015), as well as other waste containment facilities such as tailing dams, leachate collection ponds, sump wells and underground storage tanks (Rowe, 2012; Sharma and Reddy, 2004; Shukla and Yin, 2006). To counter these issues, most containment facilities use engineered lining systems (Rowe, 2012; Seymour, 1992; Sharma and Reddy, 2004). These lining systems are designed to create a barrier for the control of leachate contamination of soil and groundwater (Reddy et al., 1996; Shukla, 2016).

The type of lining system for the landfill facility is chosen based on the probable hazards of the wastes handled by that particular site. Liners can be single (also referred to as simple), composite or double (Rowe, 2012; Shah, 2000; Shukla, 2016). Furthermore, the liners might be artificial or natural, such as compacted clays (Daniel, 1984; Harrop-Williams, 1985), silty soils (Holtz, 1985), mine tailings (Jessberger and Beine, 1981) or sand-bentonite mixtures (Chapuis, 1990). Figure 1 shows the schematic profile of a typical single-liner system which consists of a leachate collection layer $\left(k \sim 10^{-1} \mathrm{~m} / \mathrm{s}\right)$, a compacted clay layer $\left(k \sim 10^{-9} \mathrm{~m} / \mathrm{s}\right)$ covered with high-density polyethylene (HDPE) geomembrane (GMB) and a leak detection/recovery layer $\left(k \sim 10^{-1} \mathrm{~m} / \mathrm{s}\right.$ ), where $k$ is the hydraulic conductivity (Shukla and Yin, 2006). 
Resistivity profiles of Perth soil in

Australia in leak-detection test

Pandey, Shukla and Habibi

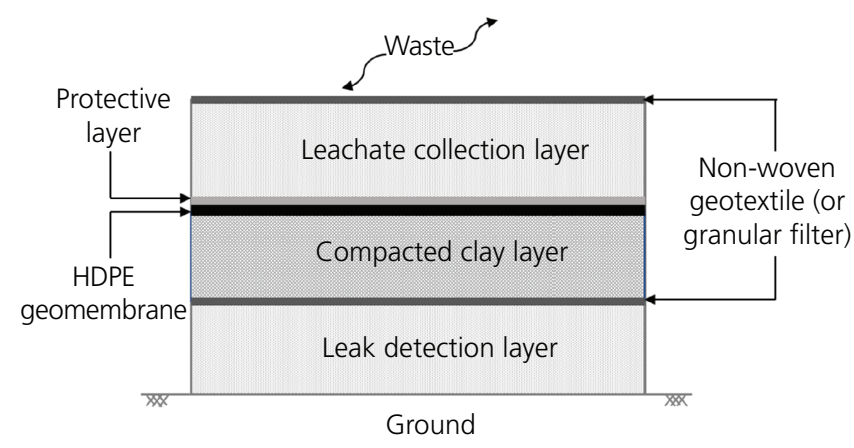

Figure 1. Schematic diagram profile of a single-liner system. HDPE, high-density polyethylene

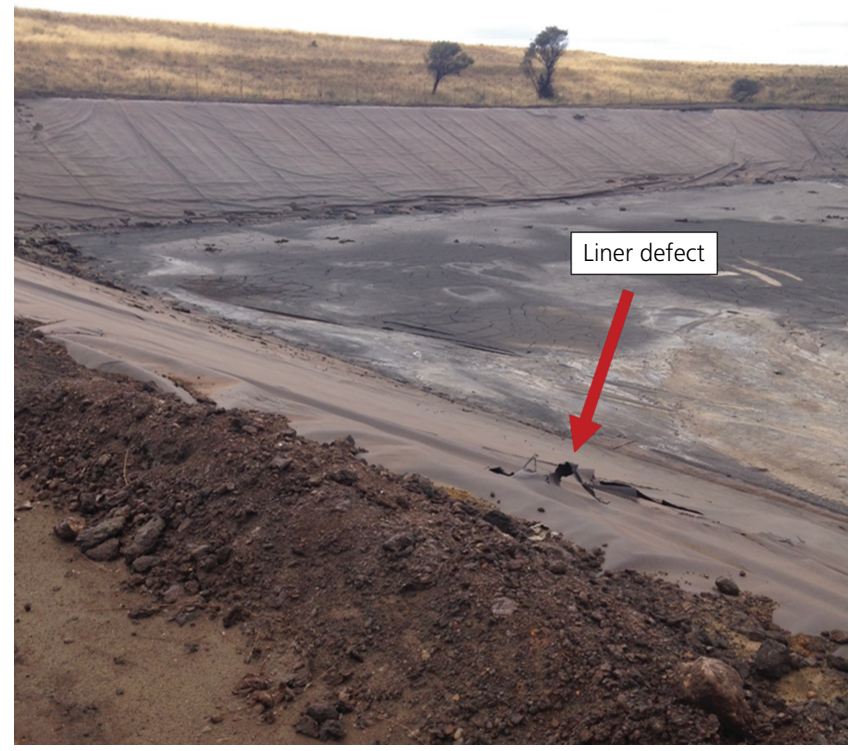

Figure 2. A typical leachate collection pond lined with $\mathrm{GCL}$
While the liners are expected to be intact over their operating lifespan, due to various factors such as poor placement assurance, insufficient quality control and harsh conditions of operation, it is observed that the integrity of these liners is often compromised (Buss et al., 1995; Giroud, 1984; Giroud and Bonaparte, 1989; Hoyos et al., 2015). Defects frequently develop in liners, resulting in leachate leakages and consequent contamination issues (Ben Othmen and Bouassida, 2013). Figure 2 shows the photograph of a typical empty leachate collection pond, lined with geosynthetic clay liner (GCL). Leaks have developed in the liner, consequently resulting in the leakage of leachates to the soil and groundwater.

In order to prevent the hazardous impacts of leachate contamination from being magnified, it is essential to detect leakages in a timely fashion and to execute adequate mitigation measures (Oh et al., 2008; Pandey and Shukla, 2017). Therefore, various methods of leak detection are practised by different waste containment facilities. Table 1 lists some of the methods used for the detection of leakages through liners. Some conventional methods of leak detection are groundwater monitoring wells, lysimeter, diffusion hoses, capacitance sensors, tracers, and so on (Hix, 1998; Oh et al., 2008). The geophysical methods used are resistivity cone penetration test, ground penetration radar, time domain reflectometry, and so on (ASTM D 6431-99 (ASTM, 2010); Oh et al., 2008). Most of these methods are cost and time intensive and hence prove ineffective (Mohamed et al., 2002). In addition, it is essential to detect leakage issues as soon as they arise so that the impact to the environment and the associated costs for remediation can be minimised. Hence, the use of the electrical resistivity method for leak detection is widely prevalent for early leakage detection (ASTM D 6747-15 (ASTM, 2015), ASTM D 7002-16 (ASTM, 2016a), ASTM D7240-06 (ASTM, 2011), ASTM D 770316 (ASTM, 2016b), ASTM D 7953-14 (ASTM, 2014)), because of its ease of installation and operation and relatively low expenditures (Ben Othmen and Bouassida, 2013; Oh et al., 2008). This method is based on the electrical resistivity changes produced in soil due to its contamination by leachates.

Table 1. Leak detection methods

\begin{tabular}{|c|c|c|}
\hline Leak detection methods & Advantages & Disadvantages \\
\hline $\begin{array}{l}\text { Groundwater monitoring } \\
\text { wells }\end{array}$ & Detects contaminant plumes & Time-consuming, expensive, localised \\
\hline Lysimeter & Detects contamination & $\begin{array}{l}\text { Laboratory testing required, high operating cost, } \\
\text { cannot identify leak point }\end{array}$ \\
\hline Diffusion hoses & $\begin{array}{l}\text { Readily available components, automatic, } \\
\text { low operating cost }\end{array}$ & Useful only for leachates with vapour \\
\hline Capacitance sensors & Readily available, automatic & Detects any moisture \\
\hline Tracers & $\begin{array}{l}\text { Effective at any stage of landfilling, unaffected } \\
\text { by leachate composition }\end{array}$ & High operating cost, does not locate exact leak point \\
\hline $\begin{array}{l}\text { Electrochemical } \\
\text { sensing cables }\end{array}$ & Widely available & $\begin{array}{l}\text { Detects only some contaminants, site-specific, must be } \\
\text { pre-installed }\end{array}$ \\
\hline Geophysical methods & Effective in locating contaminated zones & $\begin{array}{l}\text { Not easy to operate, depends on detection of } \\
\text { post-contamination plume }\end{array}$ \\
\hline Two-electrode methods & Useful for detecting leaks in pre-existing landfills & $\begin{array}{l}\text { Only indicates existence of a leak, cannot be used for } \\
\text { active landfills }\end{array}$ \\
\hline Electrode grid method & Easy to install and operate, low operating cost & High capital cost \\
\hline
\end{tabular}


Table 2. Physical properties of Perth sandy soil

\begin{tabular}{lc} 
Property & Value \\
\hline Specific gravity of soil solids, $G_{\mathrm{s}}$ & $2 \cdot 68$ \\
Coefficient of uniformity, $C_{\mathrm{u}}$ & $2 \cdot 27$ \\
Coefficient of curvature, $C_{\mathrm{C}}$ & $1 \cdot 22$ \\
Effective size, $D_{10}$ : $\mathrm{mm}$ & $0 \cdot 15$ \\
Minimum dry unit weight, $\gamma_{\mathrm{d} \text { min }}: \mathrm{kN} / \mathrm{m}^{3}$ & $14 \cdot 02$ \\
Maximum dry unit weight, $\gamma_{\mathrm{d} \text { max }} \mathrm{kN} / \mathrm{m}^{3}$ & $15 \cdot 56$ \\
Soil classification as per the Unified Soil & Poorly graded sand (SP) \\
Classification System &
\end{tabular}

In this method, a known current $(i)$ is passed through a soil specimen. The resulting potential drop $(V)$ is recorded. The resistance $(R)$ of the soil is then obtained using Ohm's law, as given in the following.

1. $V=i R$

It is a well-known fact that although different soil types have different resistivity values, all dry soils generally possess resistivity much higher than that of any contaminating fluid, such as leachate. Therefore, the addition of even a small amount of leaching liquid to the soil results in a sharp decrease in its resistivity (Fukue et al., 1999; Mitchell and Soga, 2005; Munoz-Castelblanco et al., 2012; Naghibi et al., 2016; Pandey et al., 2015). These changes can be detected easily to determine soil contamination and, therefore, to detect leakage issues (Ben Othmen and Bouassida, 2013; Mitchell and Soga, 2005; Pandey and Shukla, 2017).

Based on the electrical resistivity method, an innovative leakdetection system was developed with a view to its application in the location of leaks in liners at their onset. This system was demonstrated to be effective in leak determination. However, this technique is in a relatively nascent stage, and gaps exist in the understanding of the system. There is a significant scope for further investigation into the influence of various parameters, such as leakage duration and sensor location, on the resistivity profile of soil subjected to leak detection testing. Therefore, an attempt has been made in this paper to present insightful knowledge about the same. This work will assist practising engineers in the development of an online monitoring system for the timely detection and location of leaks in liners.

\section{Materials and methods}

Perth and its surrounding regions comprise mainly sandy soil (Stephenson and Hepburn, 1955). The soil used in this study is a good representation of Perth soil. It is extensively available throughout WA and is used widely by practising civil engineers. The properties of this soil are presented in Table 2. Figure 3 gives the scanning electron microscopy (SEM) image of this soil. It is classified as a poorly graded sand (SP) and is the foundation material for most waste impoundment systems in the Perth metropolitan region. It has been used to create the leak-detection layer in the designed leak-detection system.

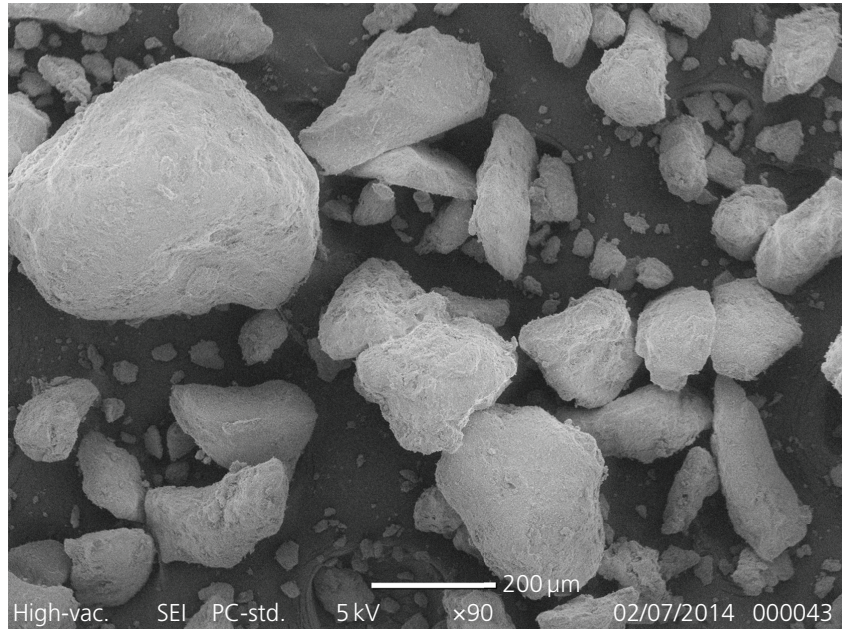

Figure 3. Scanning electron microscopy image of Perth soil

Tap water was used in this study as the leachate. This would enable testing of the system in extreme conditions, as any leaching liquid is expected to have conductivity higher than that of water (Pandey et al., 2015). Thus, if water can be detected by the leak-detection testing equipment, then the system can be demonstrated to have adequate sensitivity to detect leachate contaminations. The properties of the tap water used in this study are summarised in Table 3.

In addition, a $220 \mu \mathrm{m}$ thick GMB liner was used for the test. A piece $550 \mathrm{~mm}$ long and $250 \mathrm{~mm}$ wide was pre-cut from the GMB. A leak was intentionally introduced in the centre of the GMB piece using a gravel-size particle to simulate a real-life

Table 3. Water quality data for tap water

\begin{tabular}{lcc} 
Property & Units & Value \\
\hline $\begin{array}{l}\text { Alkalinity as calcium } \\
\text { carbonate }\left(\mathrm{CaCO}_{3}\right)\end{array}$ & $\mathrm{mg} / \mathrm{l}$ & 95 \\
Conductivity $\left(\mathrm{at} 25^{\circ} \mathrm{C}\right)$ & $\mathrm{mS} / \mathrm{m}$ & 58.5 \\
Hardness as calcium carbonate & $\mathrm{mg} / \mathrm{l}$ & 105 \\
$\mathrm{pH}$ & $\mathrm{pH}$ & $7 \cdot 72$ \\
Total dissolved solids $\left(T_{\mathrm{DS}}\right)$ & $\mathrm{mg} / \mathrm{l}$ & 385 \\
True colour & Hazen units & $<1$ \\
Turbidity & Nephelometric turbidity & $<0 \cdot 1$ \\
& unit & \\
Sodium & $\mathrm{mg} / \mathrm{l}$ & 68 \\
Calcium & $\mathrm{mg} / \mathrm{l}$ & 30.5 \\
Magnesium & $\mathrm{mg} / \mathrm{l}$ & $7 \cdot 5$ \\
Potassium & $\mathrm{mg} / \mathrm{l}$ & $5 \cdot 6$ \\
Aluminium & $\mathrm{mg} / \mathrm{l}$ & 0.02 \\
Manganese & $\mathrm{mg} / \mathrm{l}$ & $<0.002$ \\
Silicon as silicon dioxide $\left(\mathrm{SiO}_{2}\right)$ & $\mathrm{mg} / \mathrm{l}$ & 18 \\
Chloride & $\mathrm{mg} / \mathrm{l}$ & 110 \\
Sulfate & $\mathrm{mg} / \mathrm{l}$ & 19.5 \\
Nitrite plus nitrate as & $\mathrm{mg} / \mathrm{l}$ & 0.76 \\
nitrogen (N) & &
\end{tabular}

Based on personal communication with E. Tyl, Water Corporation, Western Australia, Australia (2016) 
Resistivity profiles of Perth soil in

Australia in leak-detection test

Pandey, Shukla and Habibi

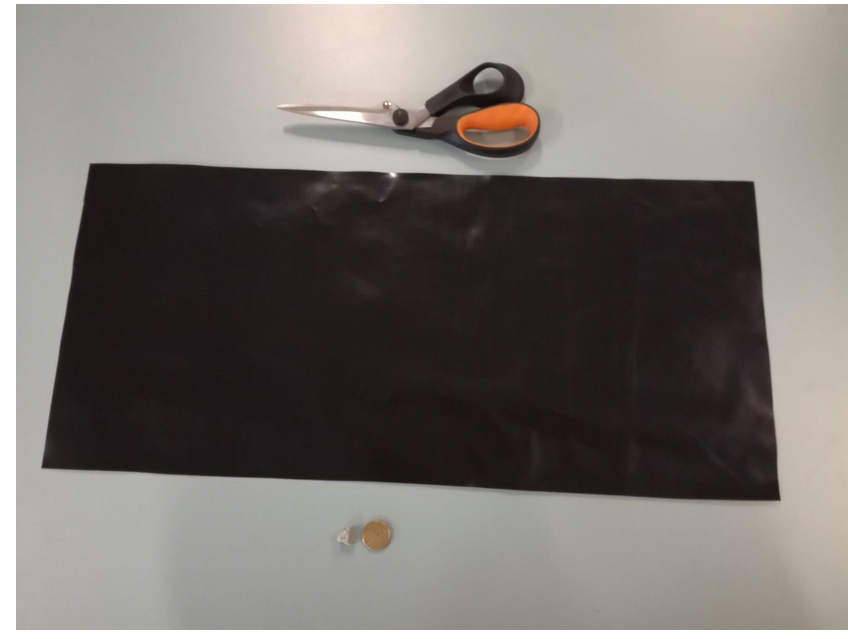

Figure 4. Photograph of the pre-cut GMB liner and the gravel-size particle used to make puncture defect

puncture defect. Figure 4 shows a photograph of the pre-cut GMB beside the gravel-size particle, as used in this study.

\section{Laboratory set-up}

Figure 5 shows the soil box used in the leak-detection system to represent the lining system. Its design has been based on the fourpoint soil resistance test method given by the Australian standard AS 1289.4.4.1-1997 (Standards Australia, 1997). A waterproof box, with internal dimensions of $500 \mathrm{~mm}$ length, $200 \mathrm{~mm}$ width and $400 \mathrm{~mm}$ height, was fabricated from a $12 \mathrm{~mm}$ thick nonconductive poly(methyl methacrylate) (PMMA) sheet. A groove of $8 \mathrm{~mm}$ dia. was made in the soil box at the height of $200 \mathrm{~mm}$ from the bottom. This groove was introduced with the intention to use it for securing the GMB liner over the soil layer.

Two brass current plate electrodes, with dimensions of $200 \mathrm{~mm}$ by $200 \mathrm{~mm}$, were fitted on either side of the soil box. Gaskets were used to waterproof the connections. Sixteen potential measuring

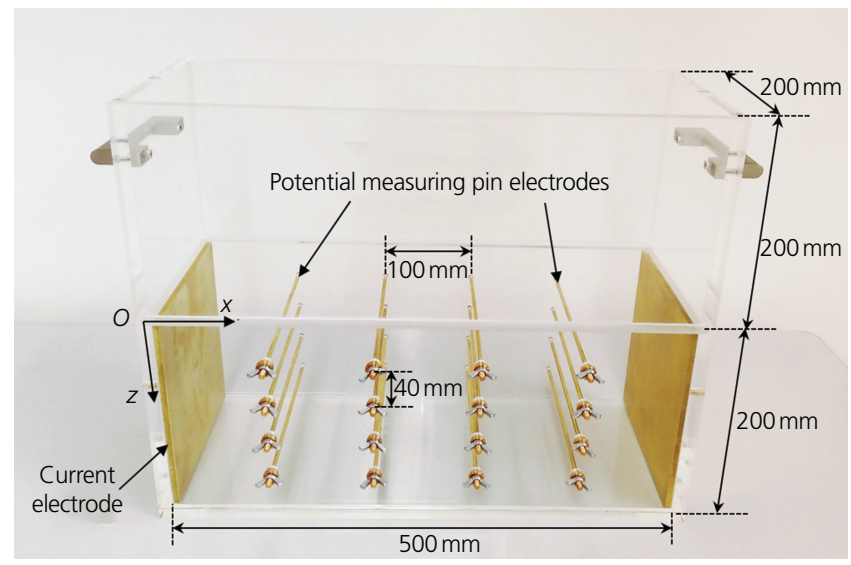

Figure 5. Soil box used in the leak-detection system point electrodes of $4 \mathrm{~mm}$ dia. were also fitted in the box, as shown in Figure 5. The experimental design of the leak detection set-up is being reported separately in more detail.

\section{Sample preparation}

The soil was oven-dried overnight at $110^{\circ} \mathrm{C}$. This soil was then used to fill the box up to a height of $200 \mathrm{~mm}$, to achieve a relative density, $D_{\mathrm{r}}$, of $100 \%$. The purpose of maintaining $D_{\mathrm{r}}=100 \%$ was to simulate a real-life leak-detection layer as used in any lining system. The box was filled using five lifts/layers to ensure homogeneity. After compacting the soil in the first layer, fourpoint electrodes were fitted laterally in the box. Then, the second soil layer was poured in, and so on. Finally, after the fifth layer was placed in, the soil layer was levelled using a wooden float before placement of the GMB.

The $550 \mathrm{~mm}$-by- $250 \mathrm{~mm}$ pre-cut GMB with a puncture defect (Figure 4) was kept over the soil. It was then secured over the soil layer using an $8 \mathrm{~mm}$ rubber gasket fitted into the $8 \mathrm{~mm}$ groove. This was done to ensure that there would be no leakages apart from the leak from the intentional puncture defect. This defect was covered initially, while the water was filled over the GMB, and then uncovered at the beginning of the test at $t=0$. Here, $t$ is the duration for which the leakage was allowed. It is also the time at which the resistance was recorded.

\section{Testing procedure}

Figure 6 shows the experimental set-up used in this study. It consists of the filled soil box, used to represent the lining system, and the AEMC 6471 machine for the resistance measurement. The AEMC 6471 is a standard four-point ground resistance tester. The connections were made as indicated in the figure.

A constant head of $100 \mathrm{~mm}$ of water was maintained over the GMB for the entire test. At the time of the start of experimentation - that is, at $t=0$ - the tape that covered the GMB defect was removed. As a result, the water started leaking through the liner to the underlying soil.

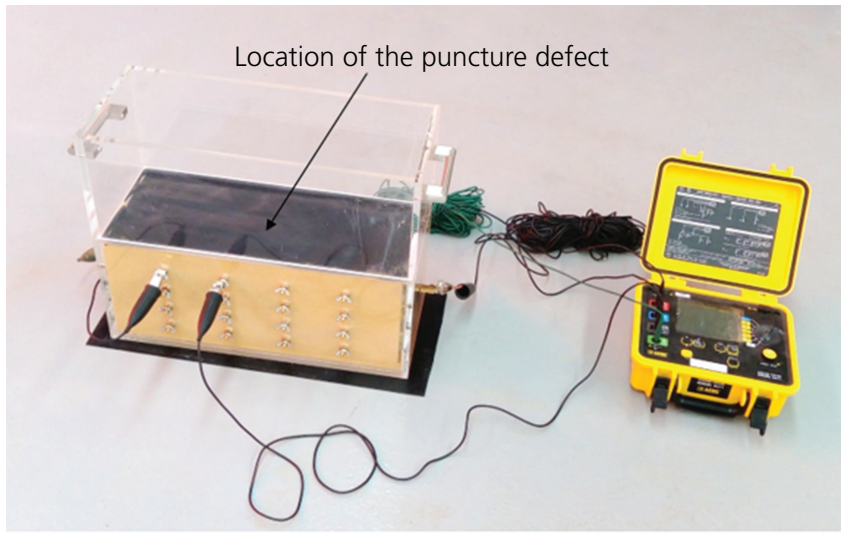

Figure 6. Experimental set-up of the leak-detection system 


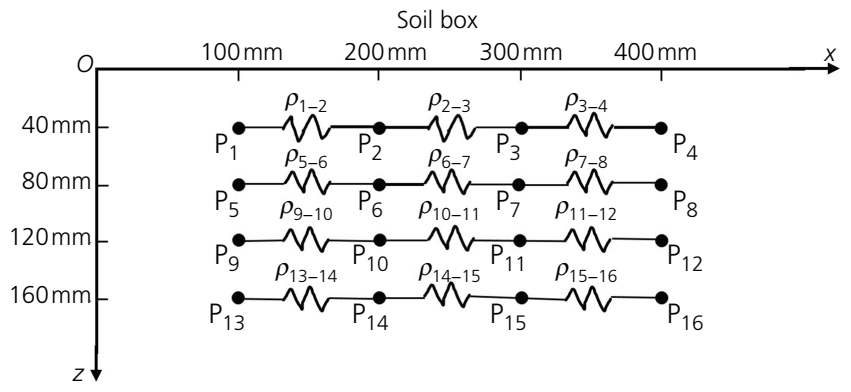

Figure 7. Representation of the soil box showing potential measuring point electrodes and associated resistivities

The electrical resistance of soil $(R)$ was obtained at 10 min time intervals using the AEMC 6471 ground resistance testing machine. The test was concluded at $t=60 \mathrm{~min}$, as the soil was observed to reach a near-saturation condition around this time.

A current with AC-input voltage of $16 \mathrm{~V}$ and AC-input frequency of $128 \mathrm{~Hz}$ was injected through the outer plate electrodes, and the resulting potential drop across each pair of point electrodes was

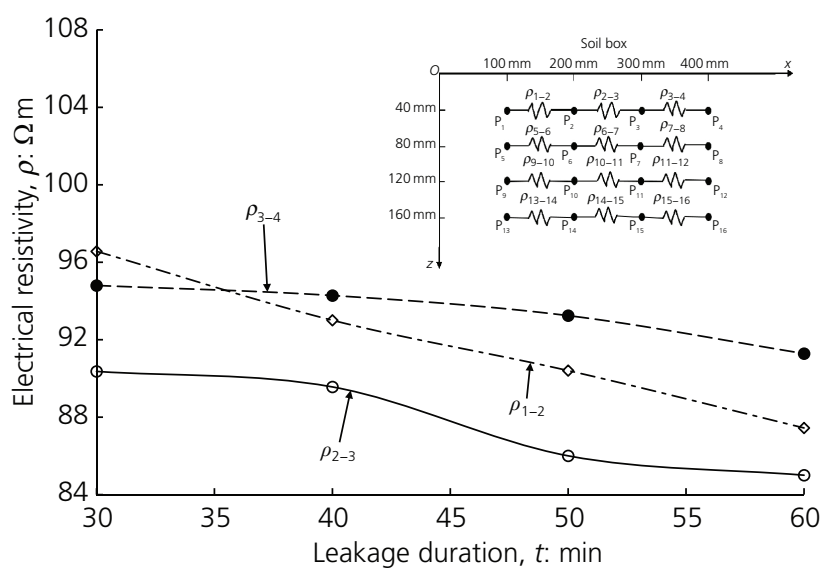

(a)

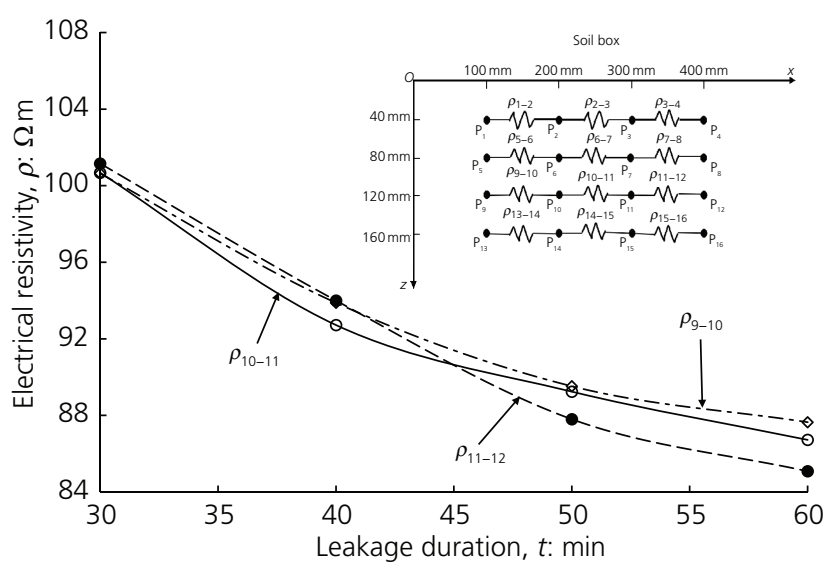

(c) measured (Figure 6). Hence, 12 resistance readings were obtained for each leakage duration, $t$. The resistivity $(\rho)$ was then calculated as per AS 1289.4.4.1-1997 (Standards Australia, 1997), using the following equation.

2. $R=\frac{\rho L}{A}$

where $A$ is the cross-sectional area $\left(\mathrm{m}^{2}\right)$ and $L$ is the length $(\mathrm{m})$ of the test specimen. It may be noted that the use of Equation 2 is justified because the voltage drop is measured between different sets of electrodes independently while the area of the plate electrodes remains the same, as considered in the derivation of Equation 2.

Figure 7 is a representation of the soil box. Here, the potential measuring point electrodes, $\mathrm{P}_{1}$ to $\mathrm{P}_{16}$, are indicated along with the associated resistivities. In this figure, $x(\mathrm{~mm})$ is the distance and $z$ $(\mathrm{mm})$ is the depth of the midpoint of each pair of electrodes, respectively. For ease of analysis, the soil resistivity obtained between a pair of electrodes was assumed to be situated at the midpoint of that electrode pair.

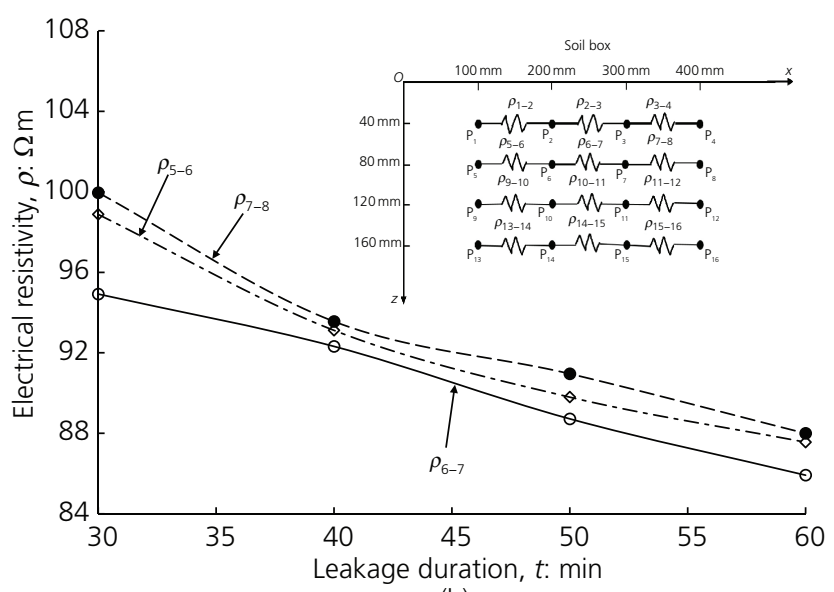

(b)

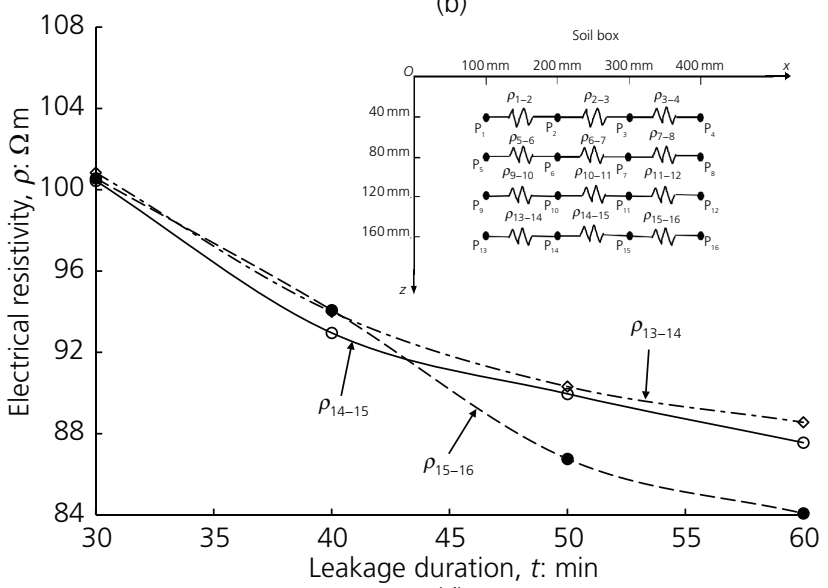

(d)

Figure 8. Resistivity profiles of electrode pairs located below the GMB liner at depths of (a) 40, (b) 80, (c) 120 and (d) $160 \mathrm{~mm}$ 


\section{Results and discussion}

Figure 8(a) gives the variation of the resistivity with leakage duration for the electrode pairs with their midpoints located at the depth $z=40 \mathrm{~mm}$. Figures $8(\mathrm{~b})-8(\mathrm{~d})$ show the same variation at $z=$ 80,120 and $160 \mathrm{~mm}$, respectively. The purpose was to observe the impact of leakage duration $(t)$ as well as the influence of the distance $(x)$ of the midpoint of the electrode pair. It was found that steady readings for the electrical resistance were not obtained at leakage durations less than $30 \mathrm{~min}$. This can be explained using the fact that the resistivity of dry sand is extremely high. Fukue et al. (1999) obtained about $10^{5} \Omega \mathrm{m}$ electrical resistivity for dry sands. Another study reported electrical resistivity values from $10^{10}$ to $10^{14} \Omega \mathrm{m}$ for silicates (Munoz-Castelblanco et al., 2012). As the standard ground resistance testing equipment used in actual field testing generally has a range of $10^{1}-10^{6} \Omega \mathrm{m}$, readings for the resistance of the soil specimen were recorded at $t \geq 30 \mathrm{~min}$.

It can be observed from Figure 8(a) that the three resistivities, $\rho_{1-2}$, $\rho_{2-3}$ and $\rho_{3-4}$, show a decrease with an increase in the leakage duration, $t$. This is as expected, because with an increase in $t$, the amount of water leaked to the soil layer would also increase. Therefore, the resistivity would decrease. It is also interesting to note that at any leakage duration $(t)$, the resistivity $\rho_{2-3}$ is lower than $\rho_{1-2}$ and $\rho_{3-4}$. This indicates that the highest amount of water from leakage is accumulated in the soil between the inner two electrodes, $\mathrm{P}_{2}$ and $\mathrm{P}_{3}$. This experimental finding is consistent with expectations, as it is known that the leak is situated directly above the midpoint of $\mathrm{P}_{2}$ and $\mathrm{P}_{3}$. As a result, it is possible to locate the leak in the liner at any time using this technique. Furthermore, it can be noticed that $\rho_{1-2}$ and $\rho_{3-4}$ are nearly same at any $t$ as they are equidistant from the introduced leak.

Similar observations were made for Figure 8(b). Resistivity was found to decrease with an increase in leakage duration. $\rho_{6-7}$ is less than $\rho_{5-6}$ and $\rho_{7-8}$ for any $t$. However, this difference was seen to be more apparent at $t=30 \mathrm{~min}$. For $t \geq 40 \mathrm{~min}$, an insignificant difference is observed.

From Figures 8(c) and 8(d), while the resistivities were generally found to register a decrease with increase in $t$, in contrast, the effect of changing $x$ was negligible. The electrodes at the depth $z=40 \mathrm{~mm}$ are the most sensitive to the leakage detection. These observations indicate that the greater the proximity of the electrode sensing system to the liner, the better the leakage detection capacity. As the depth, $z$, increases, the effect of distance, $x$, and leakage duration, $t$, is found to be negligible.

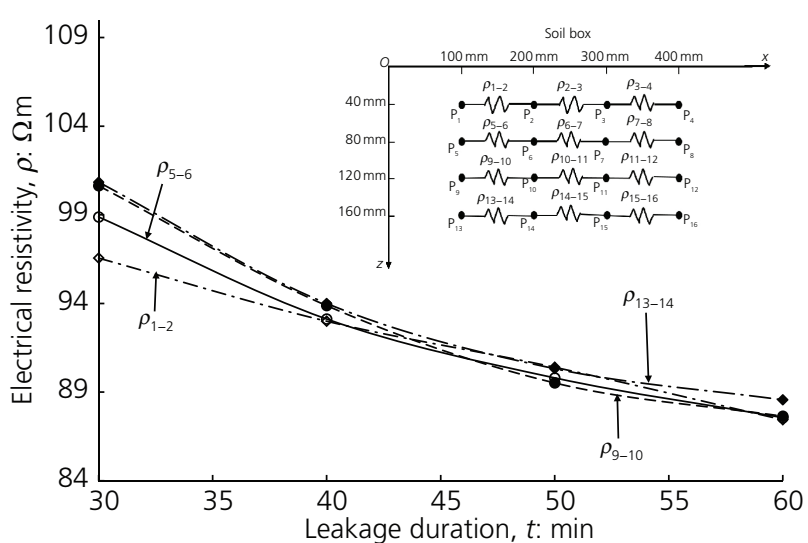

(a)

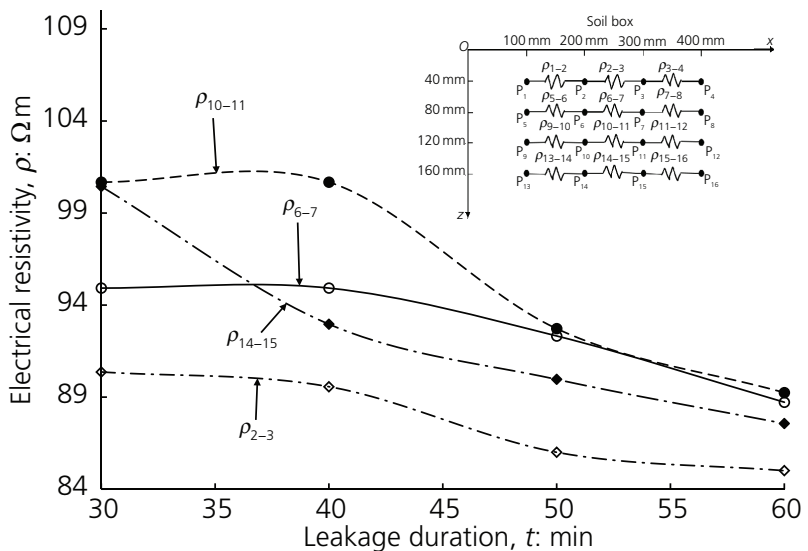

(b)

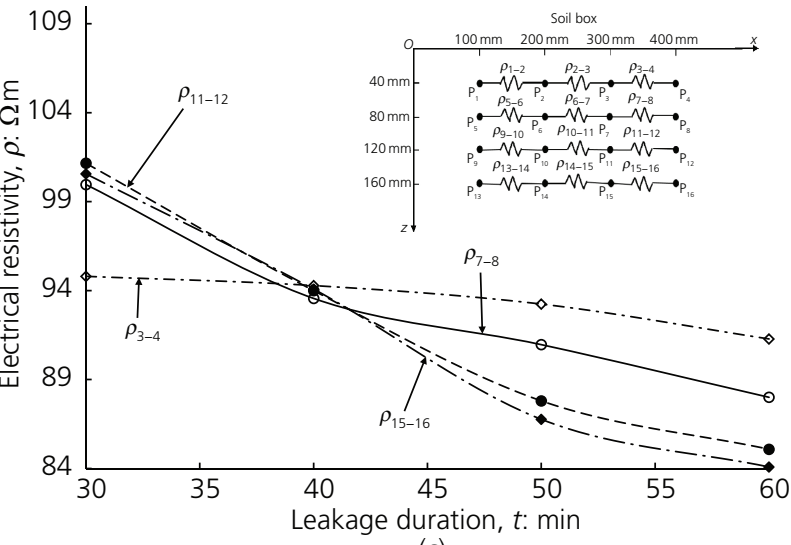

(c)

Figure 9. Resistivity profile of electrode pairs with their midpoint at distances of (a) 150, (b) 250 and (c) $350 \mathrm{~mm}$ 
Figures 9(a)-9(c) depict the resistivity profile of the soil specimen with variations in the distance of the midpoint of the electrode pairs, $x=150,250$ and $350 \mathrm{~mm}$. It can be seen that the resistivity for any particular electrode pair exhibits a decrease with an increase in the leakage duration $(t)$. Moreover, it was noticed that the resistivity was the lowest at $z=40 \mathrm{~mm}$, irrespective of $x$. This observed trend is more pronounced at $t=30 \mathrm{~min}$. However, for $t \geq 40 \mathrm{~min}$, the variations are less pronounced. This can be attributed to the fact that although attempts have been made to fill the soil box homogeneously, the soil is inherently neither homogeneous nor isotropic.

\section{Conclusions}

Based on the results and discussion presented, the following general conclusions can be made.

- The leak-detection system was found to be effective in determining leakage in the liner, irrespective of the leakage duration.

- Leaks could be located as early as $30 \mathrm{~min}$ after the development of leakage.

- The electrical resistivity across all electrode pairs was found to decrease with increasing leakage duration.

- The resistivity increased with an increase in the distance/depth from the leak point.

- The electrode sensing system that is the closest to the liner has the better ability to detect leakage. The resistivities recorded using sensors at a depth of $120 \mathrm{~mm}$ and above, showed insignificant variation with distance and leakage duration.

- The findings reported here should not be extrapolated to soil types which differ significantly from the soil used in this study.

- It may be noted that the leak-detection system will not be able to detect leakages in the liner if the soil is completely saturated.

\section{REFERENCES}

ASTM (2010) D 6431-99: Standard guide for using the direct current resistivity method for subsurface investigation. ASTM International, West Conshohocken, PA, USA.

ASTM (2011) D 7240-06: Standard practice for leak location using geomembranes with an insulating layer in intimate contact with a conductive layer via electrical capacitance technique (conductive geomembrane spark test). ASTM International, West Conshohocken, PA, USA.

ASTM (2014) D 7953-14: Standard practice for electrical leak location on exposed geomembranes using the arc testing method. ASTM International, West Conshohocken, PA, USA.

ASTM (2015) D 6747-15: Standard guide for selection of techniques for electrical leak location of leaks in geomembranes. ASTM International, West Conshohocken, PA, USA.

ASTM (2016a) D 7002-16: Standard practice for electrical leak location on exposed geomembranes using the water puddle method. ASTM International, West Conshohocken, PA, USA.

ASTM (2016b) D 7703-16: Standard practice for electrical leak location on exposed geomembranes using the water lance method. ASTM International, West Conshohocken, PA, USA.

Ben Othmen A and Bouassida M (2013) Detecting defects in geomembranes of landfill liner systems: durable electrical method. International Journal of Geotechnical Engineering 7(2): 130-135.
Bouazza A and Van Impe WF (1998) Liner design for waste disposal sites. Environmental Geology 35(1): 41-54.

Buss SE, Butler AP, Sollars CJ, Perry R and Johnston PM (1995) Mechanisms of leakage through synthetic landfill liner materials. Water and Environment Journal 9(4): 353-359.

Chapuis RP (1990) Sand-bentonite liners: predicting permeability from laboratory tests. Canadian Geotechnical Journal 27(1): 47-57.

Daniel DE (1984) Predicting hydraulic conductivity of clay liners. Journal of Geotechnical Engineering 110(2): 285-300.

Daniel DE (1993) Landfills and impoundments. In Geotechnical Practice for Waste Disposal (Daniel DE (ed.)). Springer, New York, NY, USA, pp. 97-112.

Dewha (Department of the Environment Water Heritage the Arts) (2010) National Waste Report. Dewha, Canberra, Australia. See http://www. environment.gov.au/system/files/resources/af649966-5c11-4993-8390ab300b081f65/files/national-waste-report-2010.pdf (accessed 26/09/2017).

Fukue M, Minato T, Horibe H and Taya N (1999) The micro-structures of clay given by resistivity measurements. Engineering Geology 54(1): 43-53.

Giroud JP (1984) Impermeability: the myth and a rational approach. Proceedings of the International Conference on Geomembranes, Denver, CO, USA, June, vol. 1, pp. 157-162.

Giroud JP and Bonaparte R (1989) Leakage through liners constructed with geomembranes - part I: geomembrane liners. Geotextiles and Geomembranes 8(1): 27-67.

Goldsworthy K (2010) Waste Recycling Activity in Western Australia. Western Australia Waste Authority, Perth, Australia.

Harrop-Williams K (1985) Clay liner permeability: evaluation and variation. Journal of Geotechnical Engineering 111(10): 1211-1225.

Hix K (1998) Leak Detection for Landfill Liners. National Service Center for Environmental Publications, Cincinnati, OH, USA. See https://cluin.org/download/studentpapers/leaklnfl.pdf (accessed 15/06/2017).

Holtz WG (1985) Predicting hydraulic conductivity of clay liners: discussion. Journal of Geotechnical Engineering 111(12): 1457-1459.

Hoornweg D and Bhada-Tata P (2012) What a Waste, 1st edn. World Bank, Washington, DC, USA.

Hoyos LR, DeJong JT, McCartney JS et al. (2015) Environmental geotechnics in the US region: a brief overview. Environmental Geotechnics 2(6): 319-325.

Jessberger HL and Beine RA (1981) Impermeabilisation of disposal sites by impervious blankets consisting of mine refuse. Proceedings of 10th International Conference on Soil Mechanics and Foundation Engineering, Stockholm, Sweden, vol. 4, pp. 745-746.

Mitchell JK and Soga K (2005) Fundamentals of Soil Behaviour, 3rd edn. Wiley, Hoboken, NJ, USA.

Mohamed AMO, Said RA and Al-Shawawreh NK (2002) Development of a methodology for evaluating subsurface concentrations of pollutants using electrical polarization technique. Geotechnical Testing Journal 25: $157-167$.

Munoz-Castelblanco JA, Pereira JM, Delage P and Cui YJ (2012) The influence of changes in water content on the electrical resistivity of a natural unsaturated loess. Geotechnical Testing Journal 35(1): 11-17.

Naghibi M, Abuel-Naga H and Orense R (2016) Modified odometer cell to measure electrical resistivity of clays undergoing consolidation process. Journal of Testing and Evaluation 45(4): 1261-1269.

O'Kelly BC (2016) Geotechnics of municipal sludges and residues for landfilling. Geotechnical Research 3(4): 148-179, https://dx.doi.org/ 10.1680/jgere.16.00013.

Oh M, Seo MW, Lee S and Park J (2008) Applicability of grid-net detection system for landfill leachate and diesel fuel release in the subsurface. Journal of Contaminant Hydrology 96(1-4): 69-82.

Pandey LMS and Shukla SK (2017) Detection of leachate contamination in Perth landfill base soil using electrical resistivity technique. International Journal of Geotechnical Engineering, https://doi.org/10. 1080/19386362.2017.1339763. 
Geotechnical Research

Volume 4 Issue GR4
Resistivity profiles of Perth soil in

Australia in leak-detection test

Pandey, Shukla and Habibi
Pandey LMS, Shukla SK and Habibi D (2015) Electrical resistivity of sandy soil. Géotechnique Letters 5(3): 178-185.

Perryman G and Green S (2017) Waste Recycling Activity in Western Australia - 16. Western Australia Waste Authority, Perth, Australia.

Reddy KR, Kosgi S and Motan S (1996) Interface shear behavior of landfill composite liner systems: a finite element analysis. Geosynthetics International 3(2): 247-275.

Rowe RK (2012) Geotechnical and Geoenvironmental Engineering Handbook. Springer, Berlin, Germany.

Schollum P (2010) Evaluation of the Social Optimum for the Landfill Levy in WA. Waste Authority, Perth, Australia.

Seymour KJ (1992) Landfill lining for leachate containment. Water and Environment Journal 6(5): 389-396.

Shah KL (2000) Basics of Solid and Hazardous Waste Management Technology. Prentice Hall, Englewood Cliffs, NJ, USA.

Sharma HD and Reddy KR (2004) Geoenvironmental Engineering: Site Remediation, Waste Containment, and Emerging Waste Management Technologies. Wiley, Hoboken, NJ, USA.
Shukla SK (2016) An Introduction to Geosynthetic Engineering. CRC Press, Boca Raton, FL, USA.

Shukla SK and Yin JH (2006) Fundamentals of Geosynthetic Engineering. Taylor \& Francis, London, UK.

Standards Australia (1997) AS 1289.4.4.1-1997: Methods of testing soils for engineering purposes soil chemical tests - determination of the electrical resistivity of a soil - method for sands and granular materials. Standards Australia, Sydney, Australia.

Stephenson G and Hepburn JA (1955) Plan for the Metropolitan Region of Perth and Fremantle, Western Australia: an Atlas Prepared for the Government of Western Australia (Plate 4). Government Printing Office, Perth, Australia. See http://www.planning.wa.gov.au/ dop_pub_pdf/plate4.pdf (accessed 24/11/2017).

Waste Authority (2016) Recycling Activity in Western Australia 2014-15. Waste Authority, Perth, Australia. See http://www. wasteauthority.wa.gov.au/publications/recycling-activity-2014-15 (accessed 27/09/2017).

\section{How can you contribute?}

To discuss this paper, please submit up to 500 words to the editor at journals@ice.org.uk. Your contribution will be forwarded to the author(s) for a reply and, if considered appropriate by the editorial board, it will be published as a discussion in a future issue of the journal. 